\title{
The Survey and Analysis of Excellent Senior High School Physics Teachers' Professional Growth Actuality
}

\author{
Haibin Sun \& Tingting Liu \\ Institute of Physics and Electronic Engineering, Taishan University, Tai'an 271021, China \\ E-mail: sunhbphy@163.com \\ The research is financed by the Education Science "Eleventh Five-year" Plan of Shandong Province (No.
} 2008GG179). (Sponsoring information)

\begin{abstract}
Excellent senior high school physics teachers are the backbone power in the new course reform of physics in China. The excellent senior high school physics teachers' professional growth actuality in Shandong is surveyed in this article by the self-made "Questionnaire of Excellent Senior High School Physics Teachers' Professional Growth", and by the survey, the total status and the professional growth of excellent senior high school physics teachers could be grasped.
\end{abstract}

Keywords: Excellent senior high school physics teachers, Professional growth, Questionnaire survey

\section{Introduction}

In the day that the basic education course reform is deep increasingly, teachers' education is becoming the focus noticed by people, and the growth of excellent teachers is the core topic in the focus. Excellent teachers means those teachers who could comprehensively utilize creative thinking ability and creative practice ability to labor creatively, explore new suppose, make new products, and make great contributions in the development of the education domain, and can be confirmed by the experts in the same vocation (Lai, 2004).

As the backbone power in the physics teachers, excellent physics teachers are the powerful guarantee to obtain the success of the new physics course reform. To study the growth rule of excellent physics teachers could promote the professional development of the physics teacher group, and enhance the quality of the physics teacher group of China. About the growth stage of excellent teachers, Shen Yan et al thought that the growth of excellent teachers should experience four stages including the working adaption term, the target orientation term, the self-exploring term, and the matured creation term (Shen, 2009), and Chu Huiling thought that the physics teachers' growth to the expert-type teachers should include four stages such as the adaption term, the competence term, the accumulation term, and the matured term (Chu, 2007, P.252), and Meng Zhaohui thought that the excellent physics teachers' growth course could be divide into four stages, i.e. the attention stage of physics knowledge, the attention stage of self-behaviors, the attention stage of students' behaviors, and the comprehensive attention stage of the teaching situation (Meng, 2005, P.242). According to these scholars' theoretical opinions and the teaching practice, the excellent senior high school physics teachers' growth stage could be divided into five stages including the term of adapting the physics teaching, the term of stable teaching skills, the term of enhancing the teaching level, the term of matured teaching style, and the term of becoming expert teachers in this article.

To grasp the status of excellent senior high school physics teachers' professional growth of Shandong Province and know the rule of their professional growth, and establish the base for the practice strategy promoting senior high school physics teachers' professional development purposely, the self-made "Questionnaire of Excellent Senior High School Physics Teachers' Professional Growth" is used in the survey and research (in this research, excellent senior high school physics teachers are those physical teachers with above county-level teaching honor). The questionnaire design is mainly started from the basic situation, professional activity, and professional growth of excellent physics teachers. The survey was implemented in 12 senior high schools in the Tai'an City, the Qingdao City, and the Linyi City in Shandong Province, and the survey objects are excellent senior high school teachers, and the questionnaire survey didn't note the names of investigated objects. In 80 questionnaires, all of them are returned, and 74 of them are effective, and the efficiency rate is $92.5 \%$.

\section{Result and analysis of excellent senior high school physics teachers' professional growth questionnaire survey}

2.1 Basic introduction of excellent senior high school physics teachers

In the surveyed excellent senior high school physics teachers, $64.9 \%$ of them are male, and $35.1 \%$ of them are female, and the phenomenon of sex mismatch is obvious. From Table 1, teachers from 36 to 45 years old are 
$45.9 \%$ of the total amount and $81.1 \%$ of teachers have been in this vocation above ten years, and the teachers with the graduate education level occupy $97.3 \%$, and the teachers with the senior profession title occupy $43.3 \%$. The survey result shows that most of excellent physics teachers are young and middle-aged, and the proportion of the teachers with senior profession title is high, and they generally have long teaching time, which indicates that it needs long-term teaching practice to be the excellent teachers. The survey shows that $96.3 \%$ of excellent senior high school physics teachers were graduated from the normal colleges, which indicates that the normal colleges exerted important functions in the cultivation of teachers. In the survey objects, $5.4 \%$ of them are national level backbone teachers, $8.1 \%$ of them are Shandong provincial special teachers, $2.7 \%$ of them are provincial-level teaching experts, and $21.6 \%$ of them are county-level excellent teachers (specialty top talents, academic leaders, backbone teachers, and teaching experts). These honors could reflect that excellent senior high school physics teachers have good ability of physics education and teaching recognized by the society.

\subsection{Actuality of professional development}

About the work pressure in the survey, the proportions that excellent senior high school physics teachers though it is higher and high respectively are $40.5 \%$ and $40.5 \%$, and only $16.2 \%$ of teachers thought that the work pressure is proper. $18.9 \%$ excellent physics teachers thought that the teaching workload is "very heavy", and $51.4 \%$ of them thought that the workload is "heavy", and $29.7 \%$ of them thought that the workload is "general". All excellent senior high school teachers' satisfaction about the career of physics education is higher, and $13.5 \%$ of them show "very satisfactory", and $64.9 \%$ of them show "satisfactory", and $18.9 \%$ of them show "general", and only $2.7 \%$ of them show "not satisfactory". About the stability of the education teaching work, $29.7 \%$ of them thought it is "very stable", and $59.5 \%$ of them thought it is "stable", which indicate that though the workload and work pressure of physics teacher are large, but most physics teachers love their vocation, and they have good teaching manner, strong identification to the education, and good professional sentiment.

78.4\% excellent senior high school physics teachers undertook or participated in various teaching research projects, and $83.8 \%$ of physics teachers published teaching research papers in various magazines such as "Physics Teaching", "Physics Teachers", "Middle School Physics", "Shandong Education", "Qingdao Education", "Teaching Reference of Middle School Physics", "Physics Bulletin", and "Physical Experiment". That indicates that excellent senior high school physics teachers could research and summarize various problems in the physical teaching, and have strong ability of educational scientific research.

The proportions that excellent senior high school physics teachers showed "very adaptive" and "adaptive" for the new course reform respective were $13.5 \%$ and $67.6 \%$. That shows that the excellent senior high school physics teachers have strong adaptive ability to adapt the requirements of the new physics course reform. $62.2 \%$ of excellent senior high school physics teachers made "profession learning" in their off hours, and the main channels that they got the knowledge include network learning (62.2\%), reading books $(51.4 \%)$, communication in colleagues (43.2\%), and profession training (40.5\%). That shows the excellent senior high school physics teachers have good learning habit, pay more attention to the learning of professional knowledge, and often communicate with their colleagues, and with the development of internet, the network has been the important approach for them to obtain the professional knowledge.

\subsection{Course of professional growth}

The survey shows that the teaching events which could largely influence excellent senior high school physics teachers' professional growth mainly include the large opening lesson $(70.3 \%)$, the excellent graduates' achievements (48.6\%), the teaching basic skill competition (43.2\%), and the teaching expert selection (36.1\%). And they thought the effective teaching research activities included the collective lesson preparation $(75.5 \%)$ and the lesson case discussion (51.4\%).

The survey shows that the times that excellent senior high school physics teachers enhance their teaching level in various growth stages respectively are the term of adapting the physics teaching (1-3 years), the term of stable teaching skill (4-6 years), the term of enhancing the teaching level (7-10 years), the term of matured teaching style (11-15 years), and the term becoming the expert teachers (above 16 years). $62.2 \%$ of excellent senior high school physics teachers thought that they were in the stable matured term of professional growth, and $16.2 \%$ of excellent senior high school physics teachers thought that they were in the quick development term of professional growth, and a few of them could be the scholar or expert teachers. That indicates that it needs a series of development stage to become an excellent physics teachers, and different excellent physics teachers have different development starts, and different speeds in various stages.

The survey shows that in different growth stages, the teaching emphases noticed by excellent physics teachers are different (seen in Table 2). And in the term of adapting the physics teaching, the main task of physics 
teachers is to know well the contents of physical teaching materials and the effect of classroom teaching, in order to adapt the education and teaching environment of the college as soon as possible. In the term of stable teaching skills, physics teachers begin to accumulate the teaching experiences, and form relatively stable teaching skills, and they mainly pay attention to the specialty knowledge of physics, the classroom teaching effect, and students' examination achievements. In the term of enhancing the teaching level, physics teachers could expertly undertake their physics teaching, and they mainly pay attention to the improvement of the education concept and the their teaching skills, and their investments in teaching research increase gradually, and begin to seek the advanced education concepts to instruct the teaching behaviors of physics education, and promote the enhancement of the teaching level of physics education. In the term of matured teaching style, excellent physics teachers have completely been competent for the works of physics teaching, and possessed good physical cognition structure, and accumulated deep teaching base, and possessed abundant teaching experiences and strong scientific research ability of education, and gradually formed their own teaching styles, and they mainly notice the research of teaching concepts and the enhancement of the teaching skills. In the term of becoming the expert and scholar teachers, excellent physics teachers have advanced and special education concepts, and their teaching ability is more and more mature, and their ability of teaching reflection and the course resource development are strong. In addition, in different growth stages, excellent physics teachers all could reflect their teachings in time.

About the survey item of "according to your physics teaching experiences, what are the functions of following factors for your professional growth?", five options including "very useful, useful, little useful, less useful, without use" are designed, and they are be endowed respectively by " $4,3,2,1,0$ " in the data processing, and the statics result is seen in Table 3. After statics, the average score of this item is 217. If taking the average score as the boundary, many factors such as 'reflecting his teaching, self-learning, education concept and faith, students' identification, colleague/accompanier cooperation, old teachers' instruction, teaching conflict and frustration, family support, and leaders' support" could better promote excellent senior high school physics teachers' professional growth, and the promotion function of "reflecting his teaching, and self-studying" is more obvious, and these factors are not only interior but also exterior. The factors of "teaching research and expert leading" have not promoted senior high school physics teachers' professional growth enough. This result is basically consistent with result of the questionnaire, which shows that senior high school physics teachers' professional growth has certain commonness (Sun, 2010).

\section{Conclusions}

At present, the group of Shandong provincial excellent senior high school physics teachers mainly is young and middle-aged, and the attainment rate of undergraduate education level is high, and the proportion of senior profession tile is higher, and to be the excellent teachers from general teachers needs long-term teaching practice. Normal colleges still are the main places to cultivate the teachers of physics.

Though the workload and work pressure of physics teacher are large, but most physics teachers love their vocation, and they have good teaching manner, strong identification to the education, and good professional sentiment. Excellent senior high school physics teachers could better adapt the requirements of the new course reform, and they have possessed good teaching ability of physics teaching and good scientific research ability.

The excellent senior high school physics teachers' growth stage could be divided into five stages including the term of adapting the physics teaching, the term of stable teaching skills, the term of enhancing the teaching level, the term of matured teaching style, and the term of becoming expert teachers. In different growth stages, excellent physics teachers' attentions are different, but they all could reflect their teachings in different stages. Not only the interior factors, but also the exterior factors could promote the excellent senior high school physics teachers' professional growth, and many factors such as "reflecting his teaching, self-learning, education concept and faith, students' identification, colleague/accompanier cooperation, old teachers' instruction, teaching conflict and frustration, family support, and leaders' support" could better promote excellent senior high school physics teachers' professional growth. The large opening lesson, the excellent college entrance exam achievement, and the teaching base competition could significantly promote physics teachers' professional growth, and the collective lesson preparation and the lesson case discussion are effective forms for the physics teaching and research.

\section{References}

Chu, Huiling. (2007). New Course Physics Teaching and Teachers' Professional Development. Beijing: People's Education Press. P.252. 
Lai, Xuejun. (2004). Scientific Connotation and Extension of the Concept of Excellent Teachers. Educational Review. No.4,53-58.

Meng, Zhaohui. (2005). Physics Course and Teaching Theory. Changchun: Northeast Normal University Press. P.242.

Shen, Yan, Wu, Linna \& Zhang, Jinghuan. (2009). Qualitative Research of the Growth Course of Excellent Teachers. Contemporary Educational Science. No.6,25-29.

Sun, Haibin, Liu, Tingting, \& Jiang, Yonggong. (2010). Survey and Research of Senior High School Physics Teachers' Professional Development Actuality in Shandong Province. Physics Teacher. No.1,1-3.

Table 1. Status of excellent senior high school physics teachers

\begin{tabular}{|c|c|c|c|c|c|c|c|c|c|c|c|c|c|}
\hline & \multicolumn{4}{|c|}{ Age } & \multicolumn{4}{|c|}{ School age } & \multicolumn{2}{|c|}{ Top educated level } & \multicolumn{3}{|c|}{ Profession tile } \\
\hline & $<26$ & $26-35$ & $36-45$ & $>45$ & $<5$ & $6-10$ & $11-15$ & $>15$ & Indergraduate & Post graduate & Junior & Middle & Senior \\
\hline 8 & 2.7 & 32.4 & 45.9 & 19.0 & 8.1 & 10.8 & 32.5 & 48.6 & 97.3 & 2.7 & 10.8 & 45.9 & 43.3 \\
\hline
\end{tabular}

Table 2. Excellent senior high school physics teachers' teaching emphases

\begin{tabular}{|l|c|c|c|c|c|}
\hline & $\begin{array}{c}\text { Term of adapting } \\
\text { the physics } \\
\text { teaching }\end{array}$ & $\begin{array}{c}\text { Term of stable } \\
\text { teaching skills }\end{array}$ & $\begin{array}{c}\text { Term of enhancing } \\
\text { teaching level }\end{array}$ & $\begin{array}{c}\text { Term of matured } \\
\text { teaching style }\end{array}$ & $\begin{array}{c}\text { Term of becoming } \\
\text { scholar/expert } \\
\text { teachers }\end{array}$ \\
\hline $\begin{array}{l}\text { Content of physics } \\
\text { teaching materials }\end{array}$ & $94.6 \%$ & $13.5 \%$ & $2.7 \%$ & $2.7 \%$ & $5.4 \%$ \\
\hline $\begin{array}{l}\text { Effect of classroom } \\
\text { teaching }\end{array}$ & $43.2 \%$ & $62.2 \%$ & $13.5 \%$ & $10.8 \%$ & $2.7 \%$ \\
\hline $\begin{array}{l}\text { Professional } \\
\text { knowledge of physics }\end{array}$ & $35.1 \%$ & $43.2 \%$ & $27.0 \%$ & $18.9 \%$ & $2.7 \%$ \\
\hline Education concepts & $16.2 \%$ & $37.8 \%$ & $51.4 \%$ & $38.8 \%$ & $16.2 \%$ \\
\hline $\begin{array}{l}\text { Students examination } \\
\text { scores }\end{array}$ & $35.1 \%$ & $40.5 \%$ & $16.2 \%$ & $5.4 \%$ & $5.4 \%$ \\
\hline Students' behaviors & $16.2 \%$ & $32.4 \%$ & $27.0 \%$ & $27.0 \%$ & $10.8 \%$ \\
\hline $\begin{array}{l}\text { Teachers' teaching } \\
\text { skills }\end{array}$ & $24.3 \%$ & $29.7 \%$ & $30.4 \%$ & $32.4 \%$ & $13.5 \%$ \\
\hline Teaching research & $5.4 \%$ & $18.9 \%$ & $35.1 \%$ & $37.8 \%$ & $35.1 \%$ \\
\hline $\begin{array}{l}\text { Development of } \\
\text { course resources }\end{array}$ & $5.4 \%$ & $5.4 \%$ & $21.6 \%$ & $29.7 \%$ & $37.8 \%$ \\
\hline Teaching reflection & $29.7 \%$ & $21.6 \%$ & $24.3 \%$ & $32.4 \%$ & $43.2 \%$ \\
\hline
\end{tabular}

Table 3. Score statistics of factors influencing excellent senior high school physics teachers' professional growth

\begin{tabular}{|l|c|l|c|}
\hline Reflecting his teaching & 250 & Family support & 220 \\
\hline Self-studying & 242 & Leaders' support & 218 \\
\hline Education concept and faith & 236 & Leading of experts & 212 \\
\hline Students' identification & 232 & Education of college stage & 204 \\
\hline $\begin{array}{l}\text { Cooperation of } \\
\text { colleagues/accompanier }\end{array}$ & 230 & Network learning & 204 \\
\hline Instruction of old teachers & 224 & Writing teaching research papers & 176 \\
\hline Teaching conflict and reverse & 222 & Teaching research & 174 \\
\hline
\end{tabular}

